\title{
LXI. Dissertation on Water Snakes, Sea Snakes, and Sea Serpents
}

\section{C.S. Rafinesque Esq.}

To cite this article: C.S. Rafinesque Esq. (1819) LXI. Dissertation on Water Snakes, Sea Snakes, and Sea Serpents, Philosophical Magazine Series 1, 54:259, 361-367, DOI: $10.1080 / 14786441908652245$

To link to this article: http://dx.doi.org/10.1080/14786441908652245

里 Published online: 23 Jul 2009.

Submit your article to this journal $\sqsubset \pi$

Џ Article views: 2

Q View related articles $\asymp$ 


\section{[ 361 ]}

LXI. Dissertation on Water Snakes, Sea Snakes, and Sea Serpents. By C.S. Rafinesque, Esq.

Whenever a singular phænomenon, or an extraordinary natural occurrenee, happens to be observed in the United States, whether spots in the sun, huge fossil bones, or serpents, a crowd of superficial writers hasten to offer us, instead of facts, their own ideas and conjectures on the subject, which prove, sometimes, more or less ingenious; but often wild, incorrect, or ridiculous. They are generally so much taken up by their own fancy, that they forget entirely to consult former writers of eminence on the same subjects, should they even happen to know of their existence. What idea are we to entertain of their attempts to explain those subjects, without availing themselves of the valuable writings of Herschel or La Place, Cuvier or Pinkerton, \&c.? in whose works they harl been previously and often completely illustrated. Let us listen to a group of children attempting to reason and argue on the rising of the sun, an eclipse of the moon, on the oconomy of bees, or on the structure of a whale, without asking any previous questions of their parents, and we shall find a great similarity between their thoughts and those of many of our speculative writers. They often contribute to render contemptible the subject of their inquiries, at least towards the vulgar, while it would otherwise become deeply interesting; and should their crude speculations ever reach Europe, they will certainly afford very unfavourable specimens of our hnowledge and attainments in science. These reflections have naturally suggested themselves to my mind on the present occasion.

The ancients gave the name of Water Snakes and Sea Snakes to many fishes of the eel tribe, which bear an apparent likeness to land snakes, although they differ materially on examination, by having fins and gills, and neither lungs nor scales.

Many land snakes are in the habit of going into the water, in pursuit of their food, or to escape their enemies, and they have been called Water Snakes when found in that element.

Real Water and Sea Snakes had been noticed at a very early period by navigators in the Atlantic Ocean and the Indian Seas; but as they had not been destroyed, eminent naturalists had doubted their existence, believing that eels, or similar fishes, had been mistaken for snakes.

Russel was perhaps the first writer who established their existence beyond a doubt, by describing and figuring many of them, in his splendid work on the Snakes of the Coast of Coromandel. Schneider established for them his genus Hydras, which wrong name has been with much propriety changed into Hydrophis. They have since been described in all the works on enpetology, 
by Shaw, Latreille, Daudin, \&c. ; and those last writers have divided them into four genera, Enhydris, Platurus, Pelamis, and Hydrophis; which form a peculiar tribe or natural family in the order of Snakes, to which I have given the name of Platuria (Platurians, Flat-tails or Water Snakes). They are completely distinguished from the land snakes, by having a compressed tail, which serves them as an oar or rudder, enabling them to swim with great swifness; and from the fishes of the eel tribe, by having neither gills nor fins. They breathe through lungs, at remate periods, whence they generally live near the surface of the water, like the animals of the whale tribe. They prey on fishes and sea animals, and some of them have venomous fangs. Many are known to come on land, like turtles, to deposit their eggs.

About fourteen species of Water Snakes have been described by the above authors; ten more are noticed in the travels of Peron to Australia or New Holland, one of which was ten feet long; and lately several monstrous species have been seen near our shores. Many others appear to have been perceived by former travellers; and very probably a great variety are known to sailors. The knowledge of these animals is merely emerging into notice, and may be yet greatly improved. I shall not preted to assert that they are as numerous as land snakes; but it is very likely that one hundred species at least of this tribe exist in the waters of the ocean, lakes, and rivers. Intelligent travellers, seamen, and fishermen, will gradually make us dequainted with them : meantime, I shall endeavour to give a coneise account of those we know, which may facilitate their future observations; and I shall arrange my labour in a synoptical order, coneluding by some remarks on the Sea Serpents, which are merely Sea Snakes of a very large size.

Family Platuria.-VI Genus. Ophinectes, Raf. Differing from Pelamis by having a compressed body and a carinated or angular abdomen. I arrange in this new genus all the Sea Snakes mentioned in Peron's Travels: they were all found on the western and southern shores of Australia, or New Holland; such as may have fangs ought to belong to the genus Natxix, and those with cylindrical bodies to the genus Pelamis.

1. Sp. Ophinectes cinerus, Raf. Cinerous Ophinectes. Entirely gray or ash colour.

2. Sp. Ophinectes viridis, Raf. Green Ophinectes. Entirely green.

3. Sp. Ophinectes luteus, Raf. Yellow Ophinectes. Entirely yellow.

4. Sp. Ophincctes cerulescens, Raf. Blueish Ophinectes. Entirely of a blueish colour.

5. Sp. Ophinectes versicolor, Raf. Versicolor Ophinectes. Varied 
Varied with many transverse cones, blue, white, red, green, and black. Many species are probably meant here.

6. Sp. Ophinectes maculatus, Raf. Spotted Ophinectes. Covered with many irregular large spots. Many species.

7. Sp. Ophinecles punctatus, Raf. Dotted Ophinectes. Covered with numberless small dots. Many species.

S. Sp. Ophinectes erythrocephalus, Raf. Red-headed Ophinectes. Head of a beautiful red; body *****

9. Sp. Ophinectes dorsalis, Raf. Backed Ophinectes. Dark green with large spots of yellow and light green on the back; length three or four feet; near Dewitt's Land.

10. Sp. Ophinectes major, Raf. Large Ophinectes. Green spotted with red and brown. Length from eight to ten feet; also from the shores of Dewitt's Island.

This last species appears to be the largest real Sea Snake which has fallen under the personal observation of naturalists as yet. But larger species still have been noticed at different periods. If I had the time and opportunity of perusing all the accounts of travellers and historians, I could probably bring many into notice; but this tedious labour must be postponed, and I must warn those who may be inclined to inquire into the subject, not to be deceived by the imperfect and exaggerated accounts of ancient or unknown writers. Whenever they mention neither the scales nor tail of their Sea Serpents, or when they assert they had no scales, or had gills or fins, you must in all those instances be certain that they are real fishes rather than serpents. There might, however, be found some Sea Snakes without scales, since there are such land snakes; and there fishes with scales and yet without fins: but there are no fishes without gills, and no snakes or serpents with gills! -in that important character the classical distinction consists.

Nearly all the writers whom I can remember, have been unacquainted with that obvious distinction; and they have, in imitation of the ancient Greek and Roman writer's, given the name of Sea Snakes to the large eels or fishes they happened to observe. This I apprehend is the case with Pontoppidan, in his Natural History of Norway; with Mongitore, in his Remarkable Objects of Sicily; with Leguat, in his Travels to Rodriguez Island, \&c. Their observations, and the facts they record, are notwithstanding equally valuable, since they relate to monstrous unknown fishes, which seldom fall under the observation of men. The individuals of buge species are not mumerous in nature, either on land or in water; and it is probable they often become extinct for want of food or reproduction.

Among the four different animals which have lately been observed 
served by Americans, and named Sea Serpents, only one (the Massachusetts Serpent) appears to be such: another is evidently a fish, and two are doubtful. I shall offer a few remarks on each.

1. The Massachusetts Sea Serpent. From the various and contradictory accounts given of this monster by witnesses, the following description may be collected.-It is about 100 feet!long; the body is round and nearly two feet in diameter, of a dark brown, and covered with large scales in transverse rows; its head is scaly, brown mixed with white, of the size of a horse's and nearly the shape of a dog's; the mouth is large, with teeth like a shark; its tail is compressed, obtuse, and shaped like an oar. This animal came in August last into the bay of Massachusetts, in pursuit of shoals of fishes, herrings, squids, \&ic. on which it feeds. Its motions are very quick : it was seen by a great many; but all attempts to catch it have failed, although 5000 dollars have been offered for its spoils. It is evidently a real Sea Snake, belonging prohably to the genus Pelamis, and I propose to call it Pelamis megophias, which means Great Sea Snake Pelamis. It might however be a peculiar genus, which the long equal scales seem to indicate, and which a closer examination might have decided: in that case the name of Megophias monstrosus might have been appropriated to it.

2. Capt. Brown's Sea Serpent. This fish was observed by Capt. Brown in a voyage from America to St. Petersburg, in July 1818 , near $60^{\circ} \mathrm{N}$. latitude and $8^{\circ} \mathrm{W}$. longitude, or north of Ireland. In swimming, the head, neck, and fore part of the body stood upright like a mast : it was surrounded by porpoises and fishes. It was smooth, without scales, and had eight gills under the neck; which decidedly evinces that it is not a snake, but a new genus of fish ! belonging to the eighth order Tremapnea, 28th family Ophictia, and 3d sub-family Catremia, along with the genera Sphagelranchus and Symbranchus of Bloch, which differ by having only one or two round gills under the neck. I shall call this new genus Octipos (meaning eight gills beneath); head depressed, mouth transverse, large, eight transverse gills under the neck. And its specific name and definition will be Octipos licolor. Dark brown above, muddy white beneath: head obtuse. Capt. Brown adds, that the head was two feet long, the mouth fifteen inches, and the eyes over the jaws similar to the horse's; the whole length might be 58 feet.

3. The Scarlet Sea Serpent. This was observed in the Atlantic Ocean, by the captain and crew of an American vessel from New-York, while reposing and coiled up, near the surface of the water, in the summer of 1816 . It is very likely that it was a fish, and perhaps might belong to the same genus with the foregoing; 
I shall refer it thereto, with doubt, and name it Oclipos? coccineus. Entirely of a bright crimson: head acute. Nothing further descriptive was added in the gazettes where the account was given, except that its length was supposed to be about 40 feet.

4. Lake Erie Serpent. It appears that our large lakes have huge serpents or fishes, as well as the sea. On the $3 \mathrm{~d}$ of July, 1817 , one was seen in Lake Erie, three miles from land, by the crew of a schooner, which was 35 or 40 feet long, and one foot in diameter; its colour was a dark mahogany, nearly black. This account is very imperfect, and does not even notice if it had scales; therefore it must remain doubtful whether it was a snake or a fish. I am inclined to believe it was a fish, until otherwise convinced: it might be a gigantic species of eel, or a species of the above genus Octipos. Until seen again, and better described, it may be recorded under the name of Anguilla gigas, or Gigantic Eel.

\section{ADDITIONS.}

1. The Pelamis megophias, or Great Sea Snake, appears to have left the shores of Massachusetts, and to have baffled the attempts to catch it, probably because those attempts were conducted with very little judgement. But a smaller snake, or fish, nine feet long, and a strange shark, have been taken, of which the papers give no description: let us hope that they will be described by the naturalists of Boston.

2. It appears that another large species of Water Snake is noticed by D. Felix Azara, in his Travels in South America (Paris, 1809,4 vols. $8 v o$ ), under the name of Curiyu, which may belong to the genus Pelamis, although this worthy traveller has omitted to describe its tail and scales. It may be called and characterized as follows: Pelamis curis. (Curiyu. Azara, Trav. vol. i. p. 226.) Spotted and variegated, of black and yellowish white. It measures over 10 feet, and is of the size of the leg: it lives in the lakes and rivers of Paraguay, north of the 31 st degree of latitude. It goes sometimes on land (and among shrubs), but moves heavily : it has a dreadful aspect, but does not bite; it lives on fishes, young otters, apereas, and copibaras.

3. The Water Snake of Lake Erie has been seen again, and described to be of a copper colour, with bright eves, and 60 feet long. It is added, that at a short distance balls had no effect on him: but it is omitted to mention whether it was owing to having hard seales (in which case it might be a real snake of the genus Enhydris or Pelamis), or to the indexterity of the marksman.

4. Mr. W. Lee has brought to notice another Sea Snake, seen by him many years ago near Cape Breton and Newfoundland, which was over 200 feet long, with the back of a dark green: it 


\section{On Waler Snakes, Sea Snakes, and Sea Serpents.}

stood on the water in flexuous hillocks, and went through it with impetuous noise. This appears to be the largest on record, and might well be called Pelamis monstrosus; but if there are other species of equal size, it must be called then Pelamis chloronotis, or Green-back Pelamis.

5. Dr. Samuel Mitchill has exhibited to the Lyceum of Natural History, at the sitting of the 15th September, the specimen of a species of Sea Snake from his museum, sent him some years ago from Guadaloupe, by Mr. Ricord de Mariana, which appears to be another species belonging to the genus Enhydris, to which the name of Enhydris annularis may be given: we shall add its definition and description.

Enhydris annularis. Ringed Enhydris. Whitish, ringed with black, rings broader on the back, which is cinereous and rather angular in the middle; tail broad, short, obtuse, with 70 pairs of scales underneath; more than 200 pairs of abdominal scales. This animal is about 18 inches long, covered with smooth and roundish scales above: the head is depressed, obtuse, small, covered with similar scales, and nearly black; the lips are white; a white half ring sets on the nape of the neck, and extends on each side over the eyes; a black line connects the eyes with the nostrils; an oblong white band lies below the head, longitudinally; the nostrils are round; the mouth is small, and with a few small teeth; the body is cylindrical, but the back is slightly carinated towards its centre, and of an ash colour; the black rings are narrow underneath. The tail is only two inches long, very compressed; the extremity is broader, obtuse, tipped with white, and has a slight lateral angle on each side, or a protruding lateral nerve; a similar appearance is perceptible on the upper and lower edges, which appear to be thickened; the whole tail is covered with large scales of a transverse and broad shape. This snake is found in the West Indies, in the sea, particularly on the shores of the island of Guadaloupe.

6. A fabulous account of a great Water Snake, that, according to the Indian tradition, dwelt in ancient times in a lake hear Philadelphia, may be seen in Dr. Barton's Medical and Physical Journal, vol. ii. p. 168. As another Indian tradition, relating to the mammoth, the megalona, \&c. it may be partly founded on truth.

7. The great Sea Snake has been seen again towards the middle of September, in the bay of Massachusetts, and three yellow collars observed on his neck, which has led some to believe it might be another individual and species; but this circumstance might have been overlooked before. It is not stated whether it had streaks of a lighter hue on the body, as the first was repre- 
sented to have by some witnesses. It is therefore likely that the two characters of "streaks of a lighter hue on the body, and three yellow collars on the neck," may be added to its description. The collars are described as about two inches broad, and one foot apart.

8. Dr. Mitchill informs me that General Hawkins has written a memoir on the Sea Serpents of Massachusetts, which he has sent, with a drawing, to Sir Joseph Banks; it is a paper of some length, and much interest, as it relates facts, and all the circumstances attending the appearance and natural history of those huge animals, taken upon oaths of eye witnesses. He attempts to prove, with much probability, that several individuals have been seen, and two at least, if not three species; one with three collars, another without any, and a smaller one.

LXII. Defence of English Periodical Mathematical Works, in Reply to Mr. MeiKle. By A Correspondent'.

\section{To Mr. Tilloch.}

$S_{I R},-I_{T}$ has been said that the great Newton owed every thing to the native force of his genius, and scarcely any thing to his reading; and it would seem as though this were the case with your learned correspondent, Mr. Meikle. In your last Number he advances, with an air of novelty, three distinct properties of the ellipse, one of which has been long known, while the other two are the simplest possible deductions from equally well-known propositions; w'ell-known, I mean, to a plain man like myself, who dare never venture upon announcing a proposition as new, until I have pretty carefully examined a few of the best treatises on the subject to which my supposed novelties belong.

Mr. Meikle first demonstrates that H G is less than C D. (I refer to the diagram at p. 291 of your last Number.) But this is an immediate deduction from a well-known property. Let CX be drawn, a semidiameter parallel to the tangent $\mathrm{P} K$; then it has been shown (see Robertson's Conic Sectious, book ii. props. $19,21)$ that $\mathrm{H} \mathrm{G}: \mathrm{CX}:: \mathrm{C} \mathrm{D}: \mathrm{C} \mathrm{B}$. But C X, the consequent of the first ratio, is alwavs less than $C B$, the consequent of the second: therefore $H G$, the antecedent of the frst ratio, is less than $\mathrm{C} \mathrm{D}$, the antecedent of the second.

Mr. Meikle's second proposition, namely, that $\mathrm{M} \mathrm{H}$ is greater than $C B$, is a simple deduction of the same kind; as he may find at his leisure.

With regard to the third property announced by Mr. M. viz. that $\mathrm{GH}: \mathrm{HM}:: \mathrm{DE}^{2}: \mathrm{AB}^{2}$, it is certainly "very elegant ;" 